\title{
Witchcraft Labeling: \\ Effects on Child Behavior and Self-Concept
}

\author{
Chinyere Felicia Priest
}

In this response, ${ }^{1}$ I wish to use a sociological theory, labeling theory, to increase understanding of why some accused child witches admit and confess to being witches. The narrative of Sylvain and Pastor Jean in the report by Priest, Ngolo and Stabell (2020, 3-5, 11-13) are considered.

Labelling theory was developed by Becker Howard (1963). It stipulates that the "behaviour of human beings is influenced significantly by the way other members in society label them" (Crossman 2019, np). This means that individuals act in accordance with the way that the society classifies or categorizes them. For instance, some people are labelled as wise, intelligent, foolish, lazy, or even as witches, and they tend to exhibit such behaviour. Society's positive labelling of an individual influences the exhibition of positive behaviour while negative label influences negative behaviour too. Interestingly, the label used to describe an individual may not necessarily describe the existing situation. However, with time, that label is realized.

\section{Sylvain's and Pastor Jean's Narrative}

According to his narrative, Sylvain did not believe that he was a witch but because his stepdad accused him of witchcraft, which was validated by the prophetess/ prophet, Sylvian began to gradually accept that label until he received a contrary opinion. "I told people at my church the situation, and they supported me in prayer. They rejected the accusations against me. If it were only up to me, I would have accepted everything people told me. But when pastors told me, 'They are false prophets!' this gave me the boldness to not believe everything I was told" (5) [emphasis added]. The society's labelling of him was beginning to influence his self-concept, behaviour and belief about himself.

Pastor Jean confessed to having delivered many child witches. These child witches' confessions were influenced by the society's labeling. Since they were labelled witches they had to confess to avoid harm caused to them by the deliverance ministers. Some proponents of child witches use the children's confession as evidence of being witches but the content of the confession, in many cases, are simply the children's construction based on pre-knowledge (through stories, signs given by pastors, the experience of someone they know) of the actions of witches.

Pastor Jean declared,

But others were confessing-since I forced them to. Sometimes I would press on their eyes to force them to admit. Sometimes I would have them drink vegetable oil. I would have them fast lup tol seven days. If you don't admit before that time ends, I would force you to tell me, "what was 'your ride' Ito the other world]?" And the child would say, "I fly with this stick." Others would bring me their fufu spoon ... I would burn these tools in daylight. It was making me famous. Others would tell me, "See this cut [on my body]. It's like my pocket. When I go out at night, I fill it with meat." I would tell their mother, "See, I just uncovered him." Others I would put through the process of deliverance, and after the third day, I would make them drink vegetable oil. Of course, if you fast and then drink vegetable oil, you will throw up. When they threw up, I would say, "See, he just threw up what we were looking for." (11)

Using labeling theory, we can see that labeling children witches is very detrimental to their self-concept and behaviour. It results in negative behaviour, poor self-esteem, and engaging in the activities associated with the label. Parents, family members, society, especially pastors, must speak positively about children and label them with a positive category. Research by Rosenthal and Jacobson $(1968,40)$ "showed the effects labels have on people. Students behave well or badly depending on teacher expectations. For example, if a

${ }^{1}$ This article is in response to the report by Priest, Ngolo and Stabell in this issue (2020). 
pupil is repeatedly referred to as clever and associated with leadership capabilities, the pupil can rise to a position of leadership. The individual so described may incorporate the label clever or leader as part of his or her self-concept and behave as the labels suggest" (Kibera and Kimotoki 2007, 40).

This is also true of a child who is repeatedly labeled by the society, especially if the label comes from respected figures like family members and pastors. If he/she is labeled a witch, his/her self esteem is damaged and he/she begins to exhibit deviant behavior associated with the label.

This is true of my childhood experience. I was sexually violated as a child which resulted in withdrawal from family members, feeling unloved, rejected, and defenseless. This attitude of mine, coupled with being born a triplet, was used as evidence to label me Ogbanje. "Ogbanje is believed to be an evil spirit that deliberately plagues a family with misfortune. It was believed that, within a certain amount of time from birth, Ogbanje would deliberately die and then come back and repeat the cycle, causing the family grief" (Priest 2017, 70). This label influenced my behaviour and self-perception. I would often stay alone in a dark room, avoid contact with peers, have limited conversation with family and hatred for the opposite sex; I was very fearful, and timid. I thought very lowly of myself, thinking that I am a failure, unwanted, unloved, foolish, and a nobody. I lived this way for about two decades until I found myself in a different environment where I was labelled differently (intelligent, wise, important, etc.) and this changed my whole outlook on life, my self-esteem, and my behaviour.

Our response to child witch accusation should be empathy accompanied by intentional advocacy, research, seminars, awareness, and training. For educators, positive labeling should be adopted in classifying children accused of witchcraft. For the pastors, theological training and specialized training like the one conducted in Congo is highly recommended to ensure that they are properly equipped for responding to child witch accusation. For the scholars, more research should be conducted in this line in other parts of Africa and a curriculum should be developed for the training of pastors in this area.

God commands that we "speak up for people who cannot speak for themselves. Protect the rights of all who are helpless. Speak for them and be a righteous judge. Protect the rights of the poor and needy" (Prov. 31:8-9). Children accused of witchcraft cannot speak for themselves or defend themselves for fear of the untold torture it attracts. The accused child witches are powerless to fight the accusation because they are accused by the majority and the powerful. We (the church, parents, guardians, scholars, educators, activists, government, and others) must protect the children accused of witchcraft, become their voice, and label them positively. We need to promote the enforcement of the law against child witch accusation.

\section{References}

Becker, Howard. S. 1963. Outsiders: Studies in the Sociology of Deviance. New York: Free Press.

Crossman, Ashley. 2019. How Labeling Theory Can Help Us Understand Bias and Criminal Behavior. ThoughtCo. https://www.thoughtco.com/labeling-theory-3026627. Accessed December 23, 2019.

Kibera, Lucy Wairimu, and Agnes C. Kimokoti. 2007. Fundamentals of Sociology of Education: With Reference to Africa. University of Nairobi Press.

Priest, Chinyere Felicia. 2017. Why Nigerian Christians Accuse People of Witchcraft: A Review of Cases Among the Igbo Nigerians. In Christianity and Suffering: An African Perspectives. Rodney L. Reed, ed. Pp. 53-75. UK: Langham Global Library.

Priest, Robert J., Abel Ngolo and Timothy Stabell. 2020. Christian Pastors and Alleged Child Witches in Kinshasa, DRC. On Knowing Humanity Journal 4(1):1-51.

Rosenthal, Robert, and Lenore Jacobson.1968. Pygmalion in the Classroom. The Urban Review 3(1):16-20.

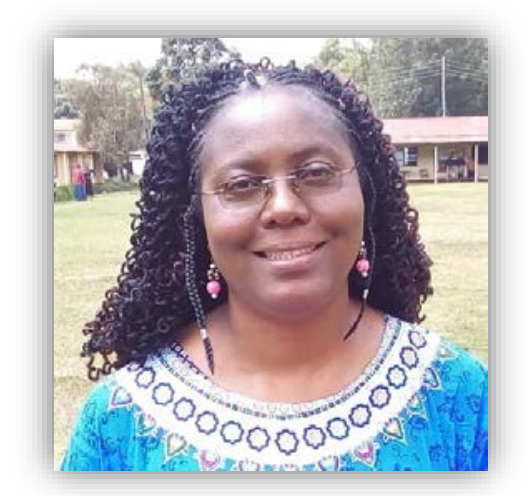

Chinyere Felicia Priest is a creative and innovative educator, missiologist, and a versatile researcher who seeks to see Christ ardently worshiped among Muslims. Her interest lies on the conversion of Christians to Islam within sub-Sahara Africa, witchcraft accusations, and gender-based violence. She holds an M.Div and M.A in Biblical studies as well as a PhD in Mission Studies.

Author email: Feliciachinvere5@gmail.com 